\title{
Analysis of Environmental Patents in Japan from 1964 to 2008
}

\author{
Kimbara Tatsuo ${ }^{1}$, Hidemichi Fujii ${ }^{2} \&$ Shinji Kaneko ${ }^{3}$ \\ ${ }^{1}$ Hiroshima Shudo University, Japan \\ ${ }^{2}$ Tohoku University, Japan \\ ${ }^{3}$ Hiroshima University, Japan \\ Correspondence: Hidemichi Fujii, Tohoku University, Japan. E-mail: hidemichfujii@gmail.com
}

Received: November 19, 2012

Accepted: December 5, 2012 Online Published: December 10, 2012

doi:10.5539/ibr.v6n1p145

URL: http://dx.doi.org/10.5539/ibr.v6n1p145

\begin{abstract}
Innovation is a key factor for achieving economic development and environmental preservation. This study examines the characteristics of environmentally innovative patents and clarifies the differences in patent data trends before and after big events and environmental policy changes. Our research target is the Japanese manufacturing sector from 1964 to 2008. Our major findings are (1) innovation was strongly triggered in pollution abatement by regulations and in product design by global standardization and market conditions, (2) product innovation becomes increasingly important for environmental management, and (3) policy needs to shift emphasis to promote product innovation in the life cycle process with an integrated perspective.
\end{abstract}

Keywords: environmental innovation, patent, pollution abatement technology, product design, Japanese manufacturing sector

\section{Introduction}

Environmental innovation is a key factor for achieving economic development and environmental preservation. This is because environmental innovation produces economic benefits while reducing environmental pollutions by changing a variety of activities and systems that cause environmental load. The Porter Hypothesis argues that proper environmental regulation lead to environmental innovation, which helps improve environmental performance and can also produce economic benefits (Porter \& van der Linde, 1995). This hypothesis sheds light on the causal processes among environmental policy, environmental innovation, competitive advantage and performance. The effectiveness of regulations is a focus of previous studies (Jaffe et al., 1995; Palmer et al., 1995; Rugman \& Verbeke, 1998). The Organization for Economic Cooperation and Development (OECD) addresses how to realize environmentally friendly growth as a significant issue on the agenda for sustainable development, and conducts studies on promotion strategy and environmental policy for environmental innovation (OECD, 2009).

At present, the development of environmental technology is one of the main policies of the Japanese government. In the Second Basic Plan for Science and Technology (2001-2005) set by the Ministry of Education and Science, the development of environmental technology is defined as one of the most significant areas of national and social issues. A variety of R\&D measures in environmental technology are programmed in the Third Basic Plan for Science and Technology (2006-2011). A number of studies on the relationship among environmental policy, innovation and competitive advantage have been done in the past decades (Rennings, et al., 2006; Wagner, 2007). Environmental technology patents have increasingly attracted practical and academic interest internationally and are used as the most reliable indicator in research for measuring environmental technology.

In 2008, the World Business Council for Sustainable Development (WBCSD) called upon firms to build a framework for providing free patent technology and encouraged them to contribute to the reduction of environmental burden. This is the Eco-Patent Commons, which intends to reduce environmental burden by firms in developing countries and SMEs through the sharing of environmental technology with free access. As of September 2010, 12 firms in Japan joined the Eco-Patent Commons program, and 102 patents for environmental technology were disclosed.

In this paper, we focus on Japan, which has scarce natural resources but invests considerably in $R \& D$ and 
achieved high economic development in the 1960s and 1970s. With the economic development, strict regulations were introduced to reduce pollution generated by economic activities. By making large efforts, firms have almost overcome the problems that generated the pollution. Pollution abatement expenditure ratio to GDP in the ten years from the 1970s to the 1980s was approximately twice as high in Japan as the ratio in the US (Lanjouw \& Mody, 1996). We examine how the development of environmental technology in Japan was affected by policy and events. We then examine the characteristics of patents as environmental innovation and clarify the differences in patent data trends before and after big events and environmental policy changes such as the Oil Crisis and Earth Summit. Our research focuses on innovations from 1964 to 2008 in the Japanese manufacturing sector. Table 1 summarizes environmental related events and environmental policy in Japan.

Table 1. History of environmental related events and environmental policy in Japan

\begin{tabular}{ll}
\hline Year & Event and Environmental Policy Change in Japan \\
\hline $1964-1972$ & - Basic Law for Environmental Pollution (1967-1993) \\
& - Air Pollution Control Law (1968) \\
& - Water Pollution Control Law (1970) \\
\hline $1973-1981$ & - Chemical Substances Control Law (1973) \\
& - First oil shock (1973) \\
& - Second oil shock (1979) \\
\hline $1982-1990$ & - Amendment of Chemical Substances Control Law [Start restriction of Chlorinated Organic Solvent] (1986) \\
& - Montreal Protocol on Substances that Deplete the Ozone Layer (1987) \\
& - Law Concerning the Protection of the Ozone Layer through the Control of Specified Substances and Other Measures (1988) \\
& - Action Program to Arrest Global Warming (1990) \\
\hline - Law Concerning Special Measures for Total Emission Reduction of Nitrogen Oxides and Particulate Matter (1992) & - Earth Summit (1992) \\
& - Basic Environment Law (1993) \\
& - The Basic Environmental Plan (Defines concept of environmental risk) (1994) \\
& - Kyoto Protocol was adopted in Conference of the Parties in Kyoto, Japan (1997) \\
& - Pollutant Release and Transfer Registers Law [PRTR Law] (1999) \\
\hline - World Summit on Sustainable Development (2002) & - Soil Contamination Countermeasures Law (2002) \\
& - Law Concerning the Promotion of the Measures to Cope with Global Warming (2002) \\
& - Amendment of Air Pollution Control Law [start restriction of VOC emission] (2006) \\
\hline $2000-2008$ &
\end{tabular}

\section{Literature Review}

A significant role of environmental policy is to promote environmental innovation to realize a sustainable society. Kammerer defines environmental innovations as "all innovations that have a beneficial effect on the natural environment regardless of whether this was the main objective of the innovation" (Kammerer, 2009: $p$ 2286). Environmental innovation aiming to reduce environmental load can be classified into technological product and process innovations and non-technological organizational innovation. Technological innovations can be approached at each phase of design, development, manufacturing, utilization, abandonment and recycling. Product innovation is the method for creating new product functions, performance and qualities that have never been realized. It is the implementation of new, or significantly improved products (goods and services) (OECD, 2009). Process innovation is a form of innovating production methods and techniques. In contrast, organizational innovation is managing business systems and structures to develop advanced services and systems. OECD (2009) classified innovation into four types: product innovation, process innovation, organizational and marketing innovation, and institutional innovation.

The primary purposes of environmental innovation include boosting resources and energy efficiency and reducing waste. Process innovation plays a significant role because all these elements are closely associated with production efficiency. As industrial life cycles mature and production scale grows, efficiency becomes more important. Therefore, existing firms tend to emphasize process innovation. Of course, pursuing product innovation or new businesses will be indispensable for market success and economic developments in the long 
run, as Abernathy postulates that the path to new industrial developments can be opened up by product innovation (Abernathy, 1978). We need to change business systems and institutions as well as technology to make radical innovation for sustainability. Institutional innovation in infrastructure is necessary for the diffusion of electric vehicles and renewable energy as a typical case.

In addition, environmental innovation should be approached from a broader perspective in terms of the life cycle. From the perspective of processes, environmental innovation is classified into two categories (Murphy and Gouldson, 2000; Frondel et al., 2008): (1) end-of-pipe technology and (2) cleaner technology aiming to prevent pollution at the source in the entire life cycle. With measures for environmental-oriented management becoming more common, the public is on its way to shifting to the preventive life cycle method. As a result, there has been much progress in environmental measures in the process of production and product design with regard to $\mathrm{CO}_{2}$, PRTR substances, water and air.

Tomas Hellström's survey on innovation of environmental technology in Germany shows that 54.3 percent of 105 samples were process innovations and 30.5 percent were product innovations (Hellström, 2007). Another survey of 588 German companies revealed that with regard to environmental innovation from 2001 and 2003, 37.2 percent of companies pursued environmental product innovation and 69.9 percent of companies pursued environmental process innovations (Rehfeld et al., 2007).

Next, interest moved on the determinants of environmental innovation. Research on the determinants of environmental technology development was done mainly in US and European manufacturing industries. In their analysis of the US manufacturing industry, Brunnermeier and Cohen (2003) revealed the causal relationship among patent numbers of environmental technology, pollution abatement cost, and monitoring frequency by government. Carrión-Flores and Innes (2010) analyzed the relationship between the number of patents for environmental technology and the emission volume of toxic chemicals. They showed that environmental innovation measured by the number of patents has a positive effect on pollution abatement. In the EU and the US, a number of studies on environmental innovation were conducted on this topic (Brunnermeier \& Cohen, 2003; Rennings et al., 2006; Rehfeld et al., 2007; Frondel et al., 2008; Horbach, 2008; Triebswetter \& Wackerbauer, 2008; Kammerer, 2009; Ziegler \& Seijas Nogareda, 2009).

As studies of the creation of innovative processes and causal relationships advance, more emphasis has been put on the fact that innovation depends on the social configuration of technology. Innovation of environmental technology is regarded as technical, economic, organizational, social and institutional changes that lead to improving environmental quality (Kline, 1989; Christensen, 1997; Huber, 2008; Triebswetter \& Wackerbauer, 2008). The process of corporate environmental innovation involves interactions between social and market conditions, such as government regulations and organizational factors. In this sense, corporate environmental innovation is perceived as a multiple and complex system rather than as a linear model such as technology push. Therefore, in conducting environmental measures, it is significant not only to directly boost effects by regulation but also to increase market demand and help economic subjects build their organizational capabilities. This accounts for an increasing number of studies that approach innovation from the perspective of environmental policy, technology, market and demand, as well as internal corporate activities. This approach provides significant hints for boosting policy effectiveness by identifying the process of creating environmental innovation and elaborating better approaches to motivate by providing incentives.

While many studies on environmental technology have been done, most are in developed western countries. In addition, preceding studies did not classify technology patent types. These studies handled patents with a different objective, such as pollution prevention technology and renewable energy generation technology, in the same way. They did not analyze patents by distinguishing different types of technology. But it is clear that business decision-making mechanisms for investing in $\mathrm{R} \& \mathrm{D}$ vary since incentives differ in pollution abatement technology and renewable energy generation technology. Then effective measures to promote environmental technology would be different. Viewing these facts, we have to make clear environmental technology development, focusing on different types of environmental patents in the Japanese manufacturing industry.

We adopted OECD (2009) criteria for classifying environmental patents into pollution abatement, energy, and product as shown in Table 2. Patents for product technology include insulation, heating, lighting and vehicles. In Figure 1, product technology patents, which include four technology types in Table 2, are divided for simplicity into building and light (insulation, heating, and lighting) and vehicle to look at the differences between the two groups. 
Table 2. Environmental patent group by type of use

\begin{tabular}{|c|c|c|}
\hline Pollution abatement & Renewable Energy & Product \\
\hline Air pollution abatement & Wind power & Insulation \\
\hline Water pollution abatement & Solar power & Heating \\
\hline \multirow[t]{5}{*}{ Solid waste abatement } & Geothermal energy & Lighting \\
\hline & Marine energy & Vehicle \\
\hline & Hydro power & \\
\hline & Biomass energy & \\
\hline & Waste-to-energy & \\
\hline
\end{tabular}

Source: OECD (2009).

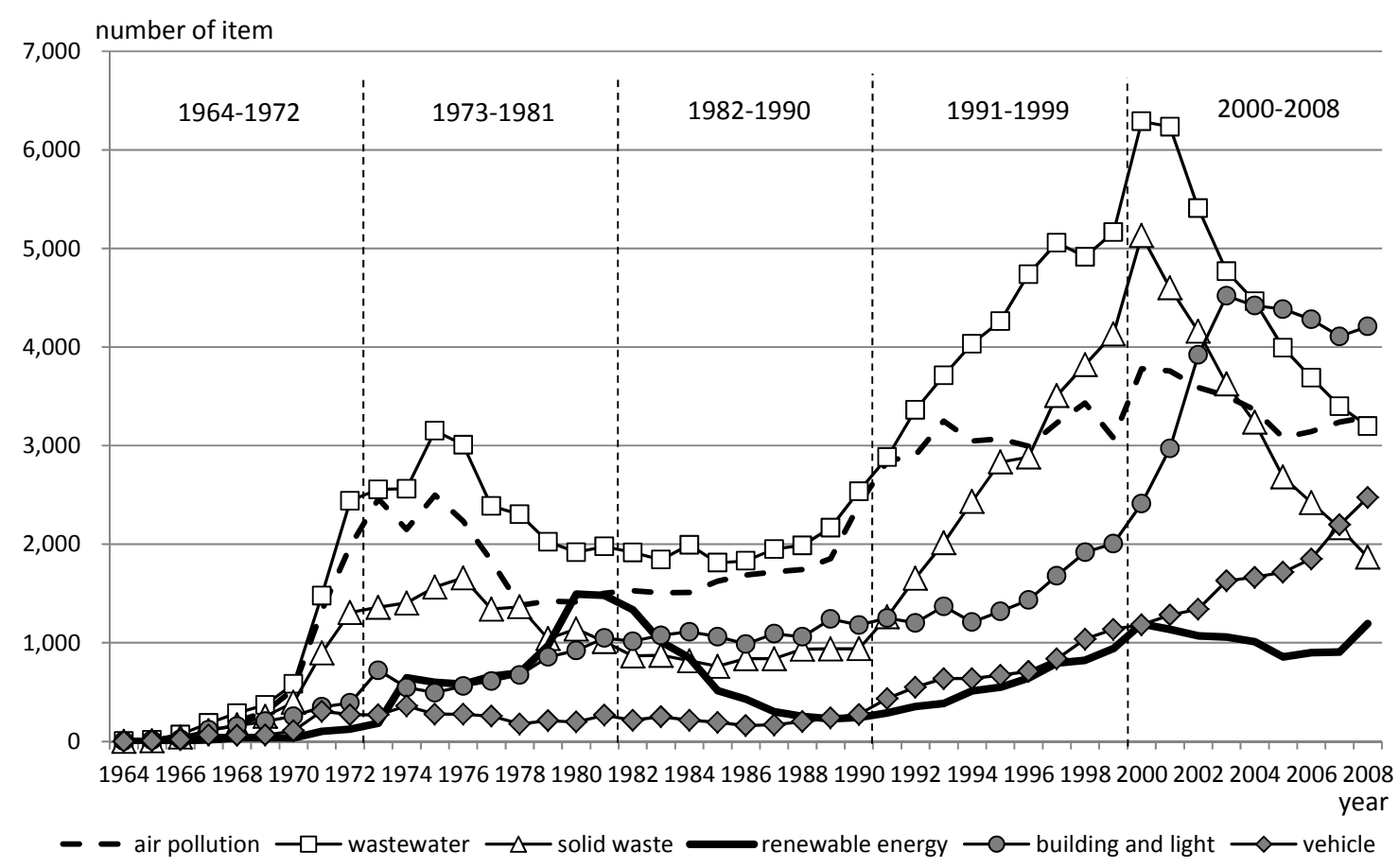

Figure 1. Time trends for environmental patents in Japan

\section{Data and Methodology}

We used patent data from the Nomura Research Institute (NRI) Cyber Patent database 2. NRI patent data used patents that passed Patent Agency of Japan screening. The year of patent means the year the patent was screened. Our study covers the 45 years from 1964 to 2008.

We divide the whole period of analysis into five 9-year periods. We then examine whether there is a different pattern of technology among these five periods. The first period is from 1964 to 1972, before the Oil Crisis, during which strict pollution control regulations were introduced. The second period is from 1973 to 1981, after the Oil Crisis. In this period, efforts to reduce energy consumption and energy efficiency improvement were critical issues. The third period is from 1982 to 1990, the economic boom. The fourth period is from 1991 to 1999, after the economic bubble and the Earth Summit. During the fourth period Environmental Management Systems such as ISO 14001 began. The fifth period is from 2000 to 2008, during which stronger commitment to environmental management under global awareness of sustainable development, and PRTR and various Recycling Acts were enacted.

The classification of patents in this paper follows OECD criteria for environmental technology. Table 3 shows the number of patents and the percentage by industry for three technology types. From Table 3, more than 83 percent of environmental patents in domestic manufacturing are accounted for by 7 industries: chemical, machine, construction, automobile, steel, electric/electronic, and ceramic. We focus on these 7 industries and analyze the trends in technology development for each type. 
Table 3. Environmental patent and share in industrial sector from 1964-2008

\begin{tabular}{lllllll}
\hline Sector & Pollution abatement & Share (\%) & Energy & Share (\%) & Product & Share (\%) \\
\hline Machine & 36,798 & $23 \%$ & 1,838 & $13 \%$ & 2,582 & $4 \%$ \\
Electric & 35,763 & $22 \%$ & 7,200 & $52 \%$ & 34,642 & $53 \%$ \\
Automobile & 23,030 & $14 \%$ & 503 & $4 \%$ & 15,164 & $23 \%$ \\
Chemical & 14,535 & $9 \%$ & 1,083 & $8 \%$ & 5,118 & $8 \%$ \\
Ceramic & 10,278 & $6 \%$ & 260 & $2 \%$ & 693 & $1 \%$ \\
Construction & 8,064 & $5 \%$ & 905 & $7 \%$ & 1,028 & $2 \%$ \\
Steel & 7,150 & $4 \%$ & 339 & $2 \%$ & 223 & $0 \%$ \\
\hline
\end{tabular}

\section{Results}

This section analyzes environmental patents by type and period to clarify the trends in environmental innovations by Japanese manufacturing companies. We describe the differences in environmental patents by time periods in Tables 4, 5, and 6. The bottom row in each of the three tables shows the results of the Kruskal-Wallis test for checking the significance of environmental patents differences among the time periods. From the Kruskal-Wallis test, we found significant differences in the number of environmental patents by time period.

First, regarding environmental patents from the 1960s to the 1970s, the number of patents related to wastewater and air pollution ranked the highest and second. By type, patents related to wastewater disposal continued highest until 2002 as shown in Figure 1. For pollution abatement, the 1970s and 1990s show the largest performance in terms of patent numbers in all 7 industries (Table 4).

Second, as shown in Table 3, patents for pollution abatement are dominated by the machine, automobile and electric industries. Raw material industries, such as steel and chemicals, show less than half of the patents in the assembly industry. In Table 5, energy patents are dominated by the electric and machine industries. Product patents are dominated by the electric and automobile industries in Table 6 .

Third, patents related to product marked a sharp increase from 2003 and the largest in 2005 in Figure 1. This means that companies focused more of their attention on product innovation than pollution abatement measures, which suggests that companies sought to obtain patents that could lead to competitive advantage in the market. The number of patents related to products was more than double the number of patents related to wastewater and air pollution measures. In Table 6, product patents sharply increased in the 1990s and 2000s in the electric and automobile industries.

Fourth, patents related to waste disposal measures ballooned in 2000 as shown in Figure 1. However, that was the peak. The number of these patents began to decrease from then onward. This suggests that a certain degree of technological innovation for waste disposal measures was achieved. Conceivably a series of recycling laws enacted around 2000 encouraged these actions. At the same time, during the 1990s in which environmental initiatives became the global norm, environmental management standards, such as ISO 14001, were introduced and environmental reports were compiled. In that situation, people concentrated much of their attention on waste reduction. A common aspect seen in many corporate environmental reports was an emphasis on the fruits of their efforts to reduce waste. At that time, many companies set the goal of zero emissions, which means the reduction of waste and increase in the recycling of waste. However, patents related to waste measures peaked in 2000, and patents related to environmental-friendly product design showed a drastic increase after 2000.

Fifth, through the whole period, a sharp increase in the number of patents was seen after new policies or events. The early 1970s had a sharp increase in the number of pollution abatement technology patents, reflecting the strict regulations for water, air and waste. The oil crisis increased innovation in energy-related and products in the electric industry. In 1990s, Earth Summit and ISO 14001 with various Recycling Acts triggered all types of patents.

Table 4. Differences in pollution abatement patent inventions by time period

\begin{tabular}{llllllll}
\hline Year & Chemical & Machine & Construction & Automobile & Steel & Electric & Ceramic \\
\hline $1964-1972$ & 718 & 963 & 56 & 392 & 311 & 979 & 98 \\
$1973-1981$ & 3,053 & 5,322 & 503 & 2,357 & 2,012 & 5,669 & 520 \\
$1982-1990$ & 1,866 & 5,487 & 767 & 2,695 & 1,518 & 5,869 & 874 \\
$1991-1999$ & 4,633 & 12,981 & 3,028 & 6,648 & 1,754 & 12,097 & 3,789 \\
$2000-2008$ & 4,265 & 12,045 & 3,710 & 10,938 & 1,555 & 11,149 & 4,997 \\
K-Wallis test & $* * *$ & $* * *$ & $* * *$ & $* * *$ & $* * *$ & $* * *$ & $* * *$ \\
\hline
\end{tabular}

Note: *, **, and $* * *$ represent $10 \%, 5 \%, 1 \%$ significance, respectively. 
Table 5. Differences in energy-related patents by time period

\begin{tabular}{llllllll}
\hline Year & Chemical & Machine & Construction & Automobile & Steel & Electric & Ceramic \\
\hline $1964-1972$ & 30 & 8 & 2 & 4 & 4 & 30 & 0 \\
$1973-1981$ & 129 & 249 & 105 & 45 & 75 & 1,869 & 35 \\
$1982-1990$ & 90 & 237 & 94 & 80 & 53 & 2,091 & 39 \\
$1991-1999$ & 354 & 495 & 308 & 157 & 78 & 1,131 & 52 \\
$2000-2008$ & 480 & 849 & 396 & 217 & 129 & 2,079 & 134 \\
K-Wallis test & $* * *$ & $* * *$ & $* * *$ & $* * *$ & $* * *$ & $* * *$ & $* * *$ \\
\hline
\end{tabular}

Note: $* * *$, and $* * *$ represent $10 \%, 5 \%, 1 \%$ significance, respectively.

Table 6. Differences in environmental product patents by time period

\begin{tabular}{llllllll}
\hline Year & Chemical & Machine & Construction & Automobile & Steel & Electric & Ceramic \\
\hline $1964-1972$ & 14 & 53 & 10 & 79 & 8 & 1,202 & 8 \\
$1973-1981$ & 127 & 201 & 82 & 173 & 32 & 4,801 & 27 \\
$1982-1990$ & 372 & 393 & 150 & 489 & 45 & 5,806 & 80 \\
$1991-1999$ & 1,003 & 762 & 413 & 3,286 & 58 & 6,245 & 273 \\
$2000-2008$ & 3,602 & 1,173 & 373 & 11,137 & 80 & 16,588 & 305 \\
K-Wallis test & $* * *$ & $* * *$ & $* * *$ & $* * *$ & $* * *$ & $* * *$ & $* * *$ \\
\hline
\end{tabular}

Note: $* * *$, and $* * *$ represent $10 \%, 5 \%, 1 \%$ significance, respectively.

Throughout the period, process innovation was consistently predominant. This pattern is the same as patent trends in Europe (Hellström, 2007). Product innovations exceeded process innovations in the number of individual patents after 2005. Environmental measures were focused on process technology over the long term, but product design showed a rapid increase from 2001.

This indicates that companies began to focus on product innovation for their development strategy. Conceivably, one of the major external factors was that the public campaign for $\mathrm{CO}_{2}$ reduction driven by the enforcement of the Kyoto Protocol boosted corporate motives for developing energy-efficient products. In addition, a significant internal factor was the strengthening of corporate strategy for securing competitive advantage through new product development. Major successful models were the development of hybrid vehicles and LED lights.

In the past decade, global economic competition has intensified. Amidst that situation, it became remarkably difficult to overcome cost gaps with developing countries, including China, and the pressure from the increased yen value through production efficiency and cost improvement by process innovation. In 2007, the Fourth Assessment Report of the Intergovernmental Panel on Climate Change (IPCC) identified the necessity for reducing $\mathrm{CO}_{2}$ emissions by 80 to 95 percent by 2050 to realize sustainability and Factor 10 became a realistic issue. In response to this situation, some companies, such as Ricoh Company, Ltd., announced their commitment to reducing $\mathrm{CO}_{2}$ and other chemical substances by 85 percent by 2050 (2009 Ricoh Group Environmental Management Report). However, such significant environmental load reduction cannot be realized by efficiency improvement measures within the framework of existing production systems. The need to take comprehensive and integrated measures throughout the product life cycle has been recognized, and the current environmental policy gradual shift to integrated models reflects that recognition. In this context, the term integrated policy refers to considering diverse factors that support innovation, as well as looking at products from the perspective of the life cycle. As mentioned above, the OECD (2009) has had intensive discussions about effective environmental initiatives for environmental innovation.

\section{Conclusion}

Environmental measures are implemented to stimulate environmental innovation with the aim of realizing a sustainable society. The first requirement for policy, therefore, is to develop initiatives that effectively promote environmental innovation. Innovations were triggered on pollution abatement technology by regulation and in product technology by global standardization and competition. One consideration should be that if environmental innovation leads to competitive advantage for companies as well as environmental improvement, then companies will be more inspired to invest in environmental innovation. In this sense, policy needs to push firms to proceed with environmental innovation (Rehfeld et al., 2007) and provide incentives for doing so. A policy that leads firms to product innovation technology on the supply side and the demand side should be adopted.

Second, since the beginning of the 21 st century, companies have clearly shifted their thinking to product 
innovation oriented toward competitive advantage. Considering the recent trends in environmental innovation, it is important to note that many environmental measures promote corporate product innovation. Product innovation contributes to the reduction of environmental load along the life cycle of product. One effective environmental measure for product innovation is a preferential tax such as for when purchasing eco-point initiatives for energy-efficient home electric appliances and for shifting to new energy sources.

Third, considering the uncertainty and complexity of innovation, policies that provide more room for discretion-based methodology with a focus on the entire life cycle to produce effective results will succeed better than regulation-based methodology. Technological success depends on multiple factors and therefore, involves much uncertainty. That is why it is essential to secure flexibility for methodological choice.

The preceding studies show that the more stringent and stable environmental policies are, the more actively companies are inspired to invest in and pursue environmental innovation (Buysse \& Verbeke, 2003). Environmental measures that can reduce the level of technological and market-based uncertainty will induce more environmental innovation. With a continued increase in ecological footprints, the requirement is to implement more integrated and effective measures.

\section{References}

Abernathy, W. J. (1978). The Productivity Dilemma: Roadblock to Innovation in the Automobile Industry. Baltimore: The Johns Hopkins University Press.

Brunnermeier, S. B., \& Cohen, M. A. (2003). Determinants of environmental innovation in US manufacturing industries. Journal of Environmental Economics and Management, 45(2), 278-293. http://dx.doi.org/10.1016/S0095-0696(02)00058-X

Buysse, K., \& Verbeke, A. (2003). Proactive environmental strategies: A stakeholder management perspective. Strategic Management Journal, 24, 453-470. http://dx.doi.org/10.1002/smj.299

Carrión-Flores, C. E., \& Innes, R. (2010). Environmental innovation and environmental performance. Journal of Environmental Economics and Management, 59, 27-42. http://dx.doi.org/10.1016/j.jeem.2009.05.003

Christensen, C. M. (1997) The Innovator's Dilemma: When New Technologies Cause Great Firms to Fail. Harvard Business School Press.

Frondel, M., Horbach, J., \& Rennings, K. (2008). What triggers environmental management and innovation? Empirical evidence for Germany. Ecological Economics, 66(1), 153-160. http://dx.doi.org/10.1016/j.ecolecon.2007.08.016

Hellström, T. (2007). Dimensions of Environmentally Sustainable Innovation: the Structure of Eco-Innovation Concepts. Sustainable Development, 15, 148-159. http://dx.doi.org/10.1002/sd.309

Horbach, J. (2008). Determinants of environmental innovation-New evidence from German panel data sources. Research Policy, 37(1), 163-173. http://dx.doi.org/10.1016/j.respol.2007.08.006

Huber, J. (2008). Technological environmental innovations (TEIs) in a chain-analytical and life-cycle-analytical perspective. Journal of Cleaner Production, 16, 1980-1984. http://dx.doi.org/10.1016/j.jclepro.2008.01.014

Jaffe, B. A., Steven, R. P., \& Paul, R. P. (1995). Environmental Regulation and the Competitiveness of U.S. Manufacturing: What Does the Evidence Tell Us? Journal of Economic Literature, 33(1), 132-163.

Kammerer, D. (2009). The effects of customer benefit and regulation on environmental product innovation. Empirical evidence from appliance manufacturing in Germany. Ecological Economics, 68, 2285-2295. http://dx.doi.org/10.1016/j.ecolecon.2009.02.016

Kline, S. (1989). Innovation Style in Japan and the United States: Cultural Bases; Implications for Competitiveness. Stanford: Stanford University Press.

Lanjouw, J. O., \& Mody, A. (1996). Innovation and the international diffusion of environmentally responsive technology. Research Policy, 25, 549-571. http://dx.doi.org/10.1016/0048-7333(95)00853-5

Murphy, J., \& Gouldson, A. (2000). Environmental policy and industrial innovation: integrating environment and economy through ecological modernization. Geoforum, 31, 33-44. http://dx.doi.org/10.1016/S0016-7185(99)00042-1

OECD. (2009). Eco-Innovation in Industry. Enabling Green Growth, OECD.

Palmer, K., Oates, W., \& Portney, P. (1995). Tightening Environmental Standards: The Benefit-Cost or the No-Cost Paradigm? Journal of Economic Perspectives, 9(4), 119-132. http://dx.doi.org/10.1257/jep.9.4.119 
Porter, M. E., \& van der Linde, C. (1995). Toward a New Conception of the Environment-Competitiveness Relationship. Journal of Economic Perspectives, 9(4), 97-118. http://dx.doi.org/10.1257/jep.9.4.97

Rehfeld, K., Rennings, K., \& Ziegler, A. (2007). Integrated product policy and environmental product innovations: An empirical analysis. Ecological Economics, 61, 91-100. http://dx.doi.org/10.1016/j.ecolecon.2006.02.003

Rennings, K., Ziegler, A., Ankele, K., \& Hoffmann, E. (2006). The influence of different characteristics of the EU environmental management and auditing scheme on technical environmental innovations and economic performance. Ecological Economics, 57(1), 45-59. http://dx.doi.org/10.1016/j.ecolecon.2005.03.013

Rugman, A. M., \& Verbeke, A. (1998). Corporate strategies and environmental regulations: An organizing $\begin{array}{lllll}\text { framework. } & \text { Strategic } & \text { Management }\end{array}$ http://dx.doi.org/10.1002/(SICI)1097-0266(199804)19:4<363::AID-SMJ974>3.0.CO;2-H

Triebswetter, U., \& Wackerbauer, J. (2008). Integrated environmental product innovation in the region of Munich and its impact on company competitiveness. Journal of Cleaner Production, 16(14), 1484-1493. http://dx.doi.org/10.1016/j.jclepro.2007.09.003

Wagner, M. (2007). On the relationship between environmental management, environmental innovation and patenting: Evidence from German manufacturing firms. Research Policy, 36(10), 1587-1602. http://dx.doi.org/10.1016/j.respol.2007.08.004

Ziegler, A., \& Seijas Nogareda, J. (2009). Environmental management systems and technological environmental innovations: Exploring the causal relationship. Research Policy, 38(5), 885-893. http://dx.doi.org/10.1016/j.respol.2009.01.020 